\title{
Gender and Labour/Working Class History in Comparative Perspective: The Syndicalist and Wobbly Experience in the USA, Australia, and New Zealand ${ }^{1}$
}

\section{Francis Shor}

It has been over a decade since Leon Fink responded to the question posed by Liz Faue concerning "how gender contributes to ... our understanding of labor history" by contending, "beyond offering new explanations for workers' past behavior and consciousness, a gendered cultural history may provide muchneeded critical ballast for assessing alternative strategies available to labor movements." Explanations deploying a gendered cultural history have proliferated over the last decade, adding to our understanding of workers' past behavior and consciousness and providing alternative readings and strategies for national and international labour movements. Grounded in a sense that "gender...is constituted through people's lived experience with continually redefined and contested social activities and institutions," those of us labouring in the field of gender and cultural history have produced local and comparative case studies that hopefully cast new light on labour/working class history. ${ }^{3}$ This essay will draw attention to what I regard as useful theoretical perspectives on gender in labour/working class history and then apply those perspectives to the activities of workers in the early twentieth century, highlighting in particular constructions of masculinity within syndicalism and the Industrial Workers of the World (IWW) in the United States, Australia, and New Zealand.

Although the IWW-or 'Wobblies'-originated in the United States in 1905 , it spread throughout the industrialised world, aided particularly by the circulation of migratory labour in the early part of the twentieth century. ${ }^{4}$ Concerned more with "agency rather than fixed organizational formation," the IWW expressed a working-class solidarity that attempted to mobilise workers around activities that contested power and authority not only in the workplace but also in the public sphere. ${ }^{5}$ The IWW attracted both committed supporters associated with the organization and partisans of the wider syndicalist cause. In effect, the IWW's discursive community extended far beyond its organisational existence, reflecting the resonance of revolutionary syndicalism within successive waves of working-class mobilisation in the early twentieth century. ${ }^{6}$

Invariably, syndicalist currents contested political and cultural formations at the macro and micro levels, challenging state policies as well as practical strategies and structures within the labour movement. As Wayne Thorpe has argued, "syndicalism was simultaneously a contributing cause, a symptom, and a beneficiary of dissatisfaction with the dominant labor strategies of the period." As the 1905 call to the founding IWW convention opined: "universal 
economic evils afflicting the working class can only be eradicated by a universal working-class movement .... It must be founded on the class struggle, and its general administration must be conducted in harmony with the recognition of the irrepressible conflict between the capitalist class and the working class." 8

Although clear and consistent about the "irrepressible conflict between the capitalist class and the working class," the IWW, from 1905-1908, was bitterly divided between rival factions, one more clearly identified with syndicalism and one that followed the political line of Daniel De Leon of the Socialist Labor Party. The latter's embrace of both industrial and political action led to severe strain on the early years of the IWW that had resonances beyond the boundaries of the United States. ${ }^{9}$ By the 1908 Wobbly convention in the US, the enmity against De Leon and his supporters became the basis for a significant split between what would become a Detroit-based De Leon minority faction and a Chicago-based majority faction that repudiated the political orientation represented by De Leon.

It was the Chicago faction that extended the IWW influence within labour and working class circles in New Zealand from 1908-1914 and in Australia from 1908 until the outlawing of the organisation in $1917 . .^{\circ}$ Unlike the US, however, both New Zealand and Australia had institutionalised mediation and arbitration by the beginning of the twentieth century. Moreover, Australia had a Labor party that had achieved electoral successes at the state and federal levels during this period. ${ }^{11}$ Hence, the IWW in New Zealand, especially from 1911-1914, and Australia, from 1914-1917, rode the wave of syndicalist rejection of state regulation and labour reform even while attempting, in opposition to the US experience, to bore from within labour organizations. More germane to the thesis of this essay, the Australian IWW articulated a form of oppositional masculinism during World War I that made it anathema to the more 'respectable' Labor party and trade union leadership.

In order to consider the complex constructions of gender within the IWW and the broader syndicalist movement, I want to explore, in particular, the forms of oppositional or alternative masculinism embodied by syndicalist-oriented Wobblies in the United States, New Zealand, and Australia. In confronting hegemonic constructions of masculinity, the IWW enacted a gendered form of protest that built on and extended a version of working-class masculinity that often deviated from respectable norms within the working class while reinforcing new codes of solidarity. According to one historian of this phenomenon, "for many in the working class, uncertain about their manly status in the workplace, periodic protest, shared among brothers, was a vital way to claim their masculinity, a reward in itself."'12 Constructions of gender were therefore reconfigured by the insistent militancy of syndicalism in ways that instantiated an oppositional masculinism. It was this period that Christopher Lasch called the "syndicalist moment" and which prompted even the determined (or over- 
determined, if you like) Marxist historian, Eric Hobsbawm, to assert: "between 1905 and 1914 the typical revolutionary in the west was likely to be some kind of revolutionary syndicalist...."13 Beyond underscoring this periodization, this essay will incorporate some theoretical insights about gender and labour/working class history that might help to situate the IWW and syndicalism in a new light while further problematizing our understanding of the interactions of gender and labour/working class history.

In my previous work on the IWW, I have contended that attacks on industrial discipline and servile behavior were laced with gendered sensibilities new to a period when industrial discipline, economic efficiency, and social regularisation were the guiding imperatives in the reconstruction of power and authority in the workplace. One often finds an effort to develop an oppositional masculinity that I call "virile syndicalism" in worldwide English-language IWW newspapers calling for direct action and strikes. ${ }^{14}$ This was not just another elaboration of a crisis of masculinity, but the interface of transforming constructions of masculinity and femininity in a world where the sphere of social activities, or social praxis, was fundamentally changing. That change was not only a consequence of the relations of capital and labour, like the second industrial revolution with its attendant de-skilling of labour and managerial revolution, but also a profound re-ordering and re-inscribing of the body in the context of re-defined public and private spheres and the development of an intrusive state, noted at the time as an emergence of a servile state. Hence, examples of virile syndicalism during this period had certain common threads, even while taking on different and definite national formulations. One could read such gendered passages as the following from the Australian IWW newspaper, Direct Action: "Strike, strike, strike, if you are MEN, STRIKE, if you have the attributes of a man. And if you refuse to fight your own battles, don't blame the fat-headed weak-hearted Labor Parties, blame your spineless, emasculated slavish selves." ${ }^{\prime 5}$ Or, one could hear Wobblies in the US singing the chorus of a famous Joe Hill tune, "There is Power in the Union": "There is pow'r, there is pow'r / In a band of workingmen / When they stand hand in hand / That's a pow'r, that's a pow'r / That must rule in every land / One Industrial Union Grand."

With their emphasis on masculine power, the IWW's gendered language can be examined within the theoretical framework presented by historians of gender like Joan Scott, who insist that "gender is a primary field within which or by means of which power is articulated."16 Work like Scott's is foundational to my own conceptualization of how gender was enacted in Wobbly discourse. Furthermore, I believe that reductionist models of power that measure working class history and masculinity only through what French social theorist Jean Baudrillard calls the "mirror of production" underestimate or even neglect the role that gender and language as constitutive fields play in working-class life. ${ }^{17}$ So, like Joan Scott and other post-structuralist historians, I acknowledge 
the work of Michel Foucault; especially his heuristic insights that consider power as a shifting strategic force field where gender, class, and race/ethnicity become part of the microphysics of struggle. Moreover, Foucault's approach to how authority is internalized through "individualizing techniques of power" is a reminder not only of my personal lived experience in the steel mill, but also the lived experiences of those who contested for power in working-class history. ${ }^{18}$

Thinking about power along these lines and as something more fluid with significant cultural dimensions opens up ideas about how gender gets constructed in multiple sites and with multiple meanings, especially through the articulation of discourse. This is not so much a linguistic turn as an effort to develop an analysis that makes sense of the structures and agency of working class life. In this regard the work of Dipesh Chakrabaty on the Bengali working class offers additional perspectives of the operation of "power and authority in institutional and interpersonal arrangements." According to Chakrabaty, "An analytic strategy that seeks to establish a 'working class' as the 'subject' of its history must also engage in the discursive formation that makes the emergence of such a subject category possible. ${ }^{19}$

Understanding that discursive formation in the context of revolutionary syndicalism requires moving beyond the point of production into questions of how the public sphere was constructed at this time. As Kenneth Tucker has recently demonstrated in his study of French revolutionary syndicalism, that public sphere was contested by the discourse and activities of syndicalist unions. Furthermore, as Tucker points out: "worker movements were as much struggling to define their relationship to the emergence of new forms of instrumental and communicative knowledge as they were responding to the loss of occupational autonomy through the rise of capitalism." ${ }^{20}$ By emphasizing class conflict in daily life, revolutionary syndicalism promoted a proletarian public sphere where working-class solidarity and emancipation were enacted in competition with bourgeois and respectable plebian norms. ${ }^{21}$ On the other hand, the public sphere at this time was gendered in a way that often excluded or marginalized working-class women. Moreover, the public sphere was even more fractured by race and sexuality when we consider the work of Tera Hunter on African-American domestic workers in Atlanta, Gunther Peck on padrones and immigrant workers in the North American west, and George Chauncey's study of gay working class life in New York. ${ }^{22}$

Therefore, we need to conceive of the public sphere as contested and contradictory terrain where, following the conceptualization of "counterpublics" by the American feminist social philosopher Nancy Fraser, revolutionary syndicalists and other labour radicals elaborated "alternative styles of political behavior and alternative norms of public speech." Specifically, these revolutionary proletarians acted as "subaltern counterpublics" that, according to Fraser, 
invent and circulate counterdiscourses, which in turn permit them to formulate oppositional interpretations of their identities, interests, and needs.... Subaltern counterpublics function as spaces of withdrawal and regroupment...[and] as bases and training grounds for agitational activities directed toward wider publics. ${ }^{23}$

Hence, another way of analysing the free speech fights and strikes led by the IWW in the United States, New Zealand, and Australia is through the lens of the subaltern counterpublic that embodies, at times, significant components of oppositional masculinism or virile syndicalism.

One way of locating a syndicalist counterpublic is to consider the gendered composition of working-class cities in the early twentieth century. Auckland was a perfect location for the development of a syndicalist counterpublic and the IWW. As a major arrival point for emigrating and migratory workers, the city attracted the kind of young, single, restless, and rough men to whom the Wobblies appealed. Not unlike that of mining and logging communities, Auckland's inner city ambience engendered forms of class conflict and solidarity in the public sphere that resonated with an IWW message. ${ }^{14}$ Moreover, as IWW organizer Tom Barker noted, "at the time Auckland, being so far away from the world, had very little entertainment. People had to make their own interests and so, for the time and place, Auckland was a very active place politically." ${ }^{25}$ Open-air meetings, in particular, provided a forum for revolutionary syndicalism while creating a proletarian public sphere.

IWW masculinity challenged not only the dominant order but also a normative order within the working class. This clearly reflected a virile enactment of revolutionary syndicalism where it, in the words of David Montgomery, "extracted from the solidarities and ethical code of workers' daily lives a merciless critique of the existing structures of exploitation, power, and authority...[including] the institutions that workers had created for themselves."26 Wobbly writers and activists, in fact, refused to spare their allies in labour and the left from withering attacks in their promotion of this virile syndicalism. For the IWW in the US, the socialists were often criticized as "slowcialists." In Australia and New Zealand, the IWW and their supporters denigrated reformist labour officials and politicians. This, in turn, engaged the wrath of reform labour leaders and right-wing Labor Party politicians like William Holman and William Hughes in Australia and Edward Tregear and Mark Fagan in New Zealand. As Verity Burgmann has demonstrated in her study of the IWW in Australia, it was the right wing of the labour movement attaining political power that led the repression of the IWW in Australia. ${ }^{27}$ I would only add that there was an important gender dimension to this internal struggle that defined what constituted respectable and unrespectable manhood. 
Nowhere was this debate within the working class over constructions of masculinity more sharply divided than in arguments about sabotage. While more often a discursive than practical strategy, the IWW promotion of sabotage was aimed at contesting power and authority through a stark sense of masculine posturing at the point of production and beyond, wherever those sites of contestation manifested themselves in North America or Australasia. For example, the Wellington Watersiders, as Erik Olssen points out, embraced forms of sabotage that reflected IWW influences in their battles and wildcat strikes against the frenzied pace and reformulation of work in the pre-World War I period. ${ }^{28}$ However, those continued influences on matters of direct action and sabotage became the grounds for attacking the IWW even within the labour movement, not only by men wedded to respectable manhood, but also by radical women who saw, within such masculinist posturing in the IWW, exclusionary and selfdefeating tactics. As cited by Joy Damousi in her study of Australian socialist women:

May Brodney, a Labor activist, unionist and feminist, claimed that although she supported the views of the IWW on industrial unionism, she rejected their tactics of sabotage and dismissed their program of direct action as an "infantile form of vandalism."

Margaret Thorp was similarly not impressed by the IWW's ta tics of direct action and sabotage and was opposed to peace brought about by force because "it's the whole miserable system we have to change and there are various methods of hastening the revolution without resorting to unworthy means."29 Nonetheless, for many Wobblies their discursive use of sabotage was intimately connected to their own sense of oppositional masculinism.

Sabotage, in particular, was linked to the struggle over the microphysics of power and control over one's own sense of gendered embodiment, especially in the reconstitution of the nature and pace of work. Combating new oppressive work routines by embracing sabotage was not only a necessary challenge to the power and authority of the capitalist but also a ritualistic test by which a Wobbly could claim one's own manhood. By posing the choice of "sabotage or slavery," an article in Direct Action asked, "Will you keep private property and public property, master class morals and working class misery, capitalism and crime-or will you arise in your outraged manhood and take a stand for sabotage, solidarity and a new social order in which there will be neither master nor slave?"30

The IWW often took the lead in constructing and appealing to the primordial instincts of working men against the assault of the new individualising techniques of power embedded in scientific management and other changes in industrial capitalism, a role which put them in the forefront of direct action 
campaigns in Australia, New Zealand, and the United States. While such virile syndicalism might have had temporary appeals to more conservative unionists, the IWW trumpeted its revolutionary message against those who would control workers either at the point of production or through the authority of the state. "If in their stress on direct action and workers control the Wobblies resembled the skilled workers in the craft unions of the AFL," argues historian Melvin Dubofsky, "they distinguished themselves from their more respectable brothers and sisters in the labor movement by a disdain for 'bourgeois law' and a total commitment to revolution." ${ }^{31}$ As a reflection of this attitude, one of the American Wobbly newspapers boldly proclaimed: "the IWW is more than a labor organization. It is a revolutionary union and the very word revolutionary supposes something radically different from concepts of what constitutes labor unions. ${ }^{932}$

If sabotage became a key determinant in the constructions of IWW masculinities and splits within labour and the left, the way that gender overlapped with national and racial/ethnic constructions also exacerbated contradictions within and outside the working class. In the United States where race had such a formative role in shaping the white working class, one incident cited by David Roediger in his study of the organizing efforts of the IWW in the South is particularly instructive of the IWW's deployment of constructions of masculinity to combat racism. When Wobbly organizer Ed Lehman confronted a white worker concerning whether there were any "niggers" in the IWW-affiliated Brotherhood of Timber Workers, Lehman defended a fellow worker who happened to be black against racist accusations by charging, "he is a man, a union man, an IWW-a MAN! ... and he has proven it by his action, [which is] more than you have done in all your boss-sucking life." ${ }^{33}$

In the New Zealand context of the debate over solidarity with Waihi miners in the famous 1912 strike, the Wellington Trades and Labour Council counseled its Australian counterparts not to support the Waihi strikers. "We have decided," argued the TLC, "that the American system of warfare is not suitable in a country where the working-man's vote is of the same value as that of the managing director of the Waihi mines." 34 The reference to the "American system of warfare" was definitely aimed at the IWW's discourse and practice of class warfare. Even harsher words were generated by a resolution of the breakaway engine-drivers union at Waihi in their denunciation of the militant activities of the strikers: "we can no longer tolerate membership of a union whose officials embrace every opportunity of insulting the Empire and its rulers, of ridiculing our traditional beliefs, of scoffing at religion, and of bleating forth anti-militarism, atheism, and Revolutionary Socialism." ${ }^{35}$ Clearly, labour radicals, like the IWW, repelled those skilled segments of labour that still maintained allegiance as respectable subjects of heavenly and secular authorities.

If labour was divided over the Waihi strike, the employers and their con- 
servative supporters in the press and the Reform Party were united in taking action against the unruly workers. In a pronounced gendering of the language used to describe the contending forces as Waihi, the conservative New Zealand Herald lauded strike breakers as "manly" while denouncing strikers and their wives as "sheepish" and "hysterical." Ironically, it was the release of a government report that cited insults against the "wives of the Engine Drivers' Union," that provided the newly installed Prime Minister Massey with a handy rationale to assign additional police forces to Waihi ${ }^{36}$ Aiming to break-up the crowds of striking workers and their supporters at Waihi, mounted police were deployed. After attacking assemblies at Waihi that included women and children, the mounted police were soon dubbed "Massey's Cossacks," a reference to the IWW labeling of the forces of repression at the McKees Rocks strike of 1909 in Pennsylvania. ${ }^{37}$

If the ideological splits evident during this period separated the Wobblies from the majority of labouring men, the gender, ethnic, and class divisions within the working class posed additional problems for the IWW and for historians attempting to make sense out of the IWW experience in national, comparative, and/or transnational terms. Certainly, women and ethnic groups played a much larger role in the US IWW experience than anywhere else. At about the same time of the Waihi strike in New Zealand the Lawrence, Massachusetts textile strike, led by the IWW, revealed the contesting of gender constructions even as it highlighted the difficulties confronting the IWW in organizing multi-ethnic class solidarity. As Ardis Cameron has shown, women workers in Lawrence who took militant actions were described as "unsexed" and even "immoral." Confounding the bourgeois and Victorian constructions of women as demure and obedient, Lawrence women refused to cower in the face of violent police actions, including the use of mounted police to run down women and children. In some cases, striking women used hatpins to fend off horses. In an incident after the police had shot and killed a young woman striker, a group of Italian women happened upon a lone police officer on an icy bridge. After stripping him of his gun, club, and badge, they sliced the officer's suspenders and took off his pants-a humiliation technique popular with the "disorderly" women of Lawrence. ${ }^{38}$

Elsewhere, when working women engaged in actions that contradicted gender constructions, they also faced repression from the ruling elites and suspicion from working class men. Laura Lee Downs in her study of the syndicalist women-led strikes in wartime France in 1916 and 1917 highlights the difference in the way police labeled women strike organizers as opposed to men strike organizers. Instead of noting their political affiliations, as they did with male leaders, the police tended to identify women leaders on the basis of their sexual conduct and moral bearing. ${ }^{39}$ Nevertheless, women were able to use their working-class communal networks as critical support systems during such 
mobilisations and strikes in ways that militant working class men, obsessed with an oppositional masculinism, were often unable to replicate.

On the other hand, oppositional masculinism came to the fore especially during World War I. In examining the role of the IWW in Australia and the United States in the anti-war and anti-conscription campaigns surrounding World War I, I want to underscore the gender discourse that became even more evident during the heated debates in both countries concerning the war and conscription. While the IWW in Australia played a more seminal role in opposing World War I than did the US IWW, both national formations of Wobblies attacked all forms of servility, especially those related to the overheated patriotism of the time. In turn, both national formations of the IWW suffered tremendous political repression as a consequence of their opposition to conscription and the war, even though the Australian IWW achieved a certain success in the anticonscription campaign. ${ }^{40}$

The IWW came to prominence in Australia on a wave of working class mobilisation and discontent over the harshness of industrial capitalism, the betrayal of labour politicians, and the disruption caused by World War I. Although never larger than several thousand members and without the formal organizational structure that developed in the American IWW, the Australian Wobblies were able to capitalize on a militant community of discourse and preexisting radical working class networks, particularly in mining towns like Broken Hill, that embodied syndicalist sentiments and produced forms of social protest such as anti-conscription demonstrations and strikes during this period. ${ }^{41}$

While the IWW in the United States was a much larger organization, mobilising tens of thousands of workers in massive strikes such as Lawrence, Massachusetts and Paterson, New Jersey in the pre-1914 period, the start of the war found the IWW moving away from the large factories of the east where men and women often worked in nearly equal numbers to the midwest wheat fields, the mines of the west and southwest, and the timber ranges of the northwest where men predominated. The sense of gendered solidarity in these mining and migratory camps provided opportunities to experience a form of cultural empowerment that signaled to many wandering men that they were more than hired hands or mere cogs in a machine. John Reed, the American radical journalist, noted this cultural component when he commented about the IWW: "whenever, in the West, there is an IWW local, you will find an intellectual center-a place were men read philosophy, economics, the latest plays: where art and poetry are discussed and international politics.".42

One could also find this gendered solidarity 'down under.' Tom Barker, an IWW organizer and propagandist in Auckland and Sydney, recounted the function of the IWW locals in Australia: "migratory people looked for support when they came to a new place and if they found an IWW branch they knew they were amongst friends, and that created a spirit of solidarity that was some- 
thing more than words." the voice of the Aussie IWW, Direct Action, a desire "to seize the growing discontent and organise it for revolutionary purposes." ${ }^{\prime 4}$ Although the IWW in Australia and the United States used its communal base to "fan the flames of discontent," as American Wobbly leader, "Big Bill" Haywood noted in a letter to Direct Action: "your country is situated [so] that capitalism has not yet got a strangle hold upon the workers such as it has in this country, and the workers should take more readily to the agitation." $"$ s5

Partly as a consequence of the legalisation of trade unions in Australia through the establishment of the Arbitration Court, and the success of a Labor Party at both the state and federal level, the IWW in Australia did not have to worry about organizing for recognition as a trade union as it did in the United States. The focus, instead, became the interventionist state and the reconstitution of power and authority over workers as employees and citizens. Claiming that "the Australian IWW were the first revolutionary trade union movement who saw their main enemy as state paternalism, democracy in its 'enlightened' aspects, and set themselves to oppose security in the name of initiative and job control," historian Ian Bedford apprehends the syndicalist thrust of the IWW message while neglecting how that message incorporated a gendered discourse. ${ }^{46}$ The revolutionary agitation of the IWW in Australia evoked traditional concepts of manhood under siege by new forms of power and authority while promoting an oppositional masculinism represented in its own "message of virility, strength, and unconquerable optimism." ${ }^{37}$

The fight over the passage of conscription in Australia took on the components of a moral crusade for both sides. While the IWW was not the only, nor even the most important, working class organization that mobilised against conscription, helping to defeat the conscription referenda of 1916 and 1917, it articulated the most radical and uncompromising denunciation of conscription. According to Direct Action:

conscription is a devouring monster, which, when established in a country spreads disease, crime, and pestilence wherever it sets its filthy paw. It is a dangerous enemy to the working class, and will set back progress for many years; it will mean the shattering of many working class organizations, and the silencing of labour agitators; it will mean the suppression of many liberties we now enjoy which members of our class have fought and bled and died for. ${ }^{48}$

This image of conscription as a beast not only embodies a conventional metaphor for that which engenders moral degradation and pollution, but also implies that proponents of conscription were less than men. According to IWW propaganda, the real desecrators of manhood were those who would lead "unthinking slaves" into the abyss of war while saving "their cowardly carcass- 
128 Shor

es." ${ }^{349}$ Direct Action editorialised that "conscription denies man's ownership of his body. It violates the integrity of his soul." 50

While there was a near consensus of opposition to conscription in Australia, the question of how far the IWW in the United States should go in its anti-war campaign and what to do about conscription were matters of some contention. In a series of articles and letters to Solidarity in late 1915 and early 1916, the issue of becoming involved in anti-war activities was debated. A number of readers agreed with letter writer Frank Jahel who argued that "Militarism is the backbone of capitalism and therefore THE issue." "s1 In response, Solidarity editor, Ben Williams, articulated what appeared to be the dominant view within the IWW leadership in the US: "it would be a colossal blunder for the IWW just now to pay exclusive attention to the antimilitarist propaganda and neglect the only thing that can hope to successfully grapple with capitalism and its militarist prop. That thing is industrial organization of the working class-national and international in scope.".52

Once the United States entered the war in April 1917, the IWW faced increasing legal and extra-legal repression. The war exacerbated tendencies both in the state and the IWW that, to some extent, reconstituted the terrain on which such political antagonism was played out. For the IWW, the war had a dual effect of providing both opportunities and perils. The opportunities can be attributed to the labour shortage and the increased production of food, lumber, and copper-all in areas where the IWW rose to the occasion to organise. In the aftermath of the US declaration of war in 1917, one member from the state of Washington wrote, "I hope this damn war business is not going to set us back, as the prospect for the IWW looks very bright." ${ }^{33}$ According to Wobbly leader, Ralph Chaplin, "in the early spring of 1917 harvest stiffs were joining the IWW Agricultural Workers organization at the rate of five thousand a month." 54

By 1917, however, preparations for US entrance into the war brought into sharper focus a much more pointed Wobbly discourse on class and gender issues related to war. Soon after Ralph Chaplin took over the editorship of Solidarity, the leading IWW newspaper of the time, he penned an editorial, "Preparedness," that spelled out the IWW's explicit commitment to class war and revealed their implicit oppositional masculinist orientation. "If you are seeking preparedness," the editorial opined, "join the IWW. You will never have a better chance than Now. Take your place with your fellow workers in the trenches of the industrial war-Your war-and show that you are made of the stuff that men are made of."'55 The IWW emphasis on manhood as an expression of a militant working-class sensibility was further reflected in the Wobbly stickerette: "Don't Be a Soldier! Be a Man!" After conscription was passed into law in the United States in May of 1917, Solidarity published an article by J. Stephen Dodd entitled "Soldiers are Wanted" that proclaimed, "the 
IWW is the army of the militant working class," and urged members "to enlist for the terms of the war."

On the other hand, the IWW was faced with the immediate problem of what position to take on registration and the draft. Unlike the situation in Australia, where conscription never became law because of its defeat in two referenda, the IWW leadership became very cautious about urging opposition to conscription and draft resistance. When the whole Rockford, Illinois IWW local marched against conscription and demanded arrest in defiance of registration on 5 June 1917, Solidarity noted in its page one story that "those that did not register acted on their own accord without being coaxed by any leaders as the police claimed." ${ }^{57}$ Finally, after much back-stage maneuvering and debate, Solidarity issued a statement in its back pages signed only by the editor (Ralph Chaplin) which reiterated its anti-war position, but temporized on the matter of direct defiance of the draft law: "the IWW has placed its self [sic] on record regarding its opposition to war, and also as being bitterly opposed to having its members forced into the bloody and needless quarrels of the ruling class of different nations." ${ }^{88}$

Anticipating possible persecution because of its militancy, the IWW leadership in the United States tried to tone down its discussion of anti-draft and anti-war activity. Although Haywood insisted that the "world war is of small importance compared to the great class war," he went on to assert that the IWW "shall continue to fight for the emancipation of the working class, despite all other circumstances." ${ }^{959}$ It was the continuance of that fight, especially through the discourse of "virile" and revolutionary syndicalism, which resulted in the IWW bearing the full brunt of repression. As noted by historian William Preston, "in the wartime hysteria of 1917, Americans were in no mood to accept reasonable interpretations of the inflammatory and incendiary prose by which the IWW had lived .... By emphasizing the continuing war with the master class and by refusing to abandon the right to strike, the IWW retained the very concepts that were to ensure its suppression." "60

The repression meted out against the IWW was both legal and extralegal. The most egregious and massive vigilante action during World War I against the Wobblies took place in Bisbee, Arizona, where on an early morning in July 1917 , over 2,000 vigilantes rounded up 1,200 suspected Wobblies (killing several in the process) and deported them in cramped boxcars to the desert of neighboring New Mexico. An IWW response to the massive deportation, found in the pages of Solidarity, highlighted a convergence of the gender discursive currents that defined the Wobbly sensibility and its oppositional politics during the war. In an article entitled "The Iron Heel at Work" and in a subsequent editorial, Solidarity issued the following declamatory broadside:

the cherished traditions of "American manhood" and Anglo-Saxon fair play 
130 Shor

have been shattered to bits. The fundamental rights of American citizens have been revoked by the plug-uglies of a great corporation. And these things have been done under the mask of loyalty and with the convenient excuse of patriotism. ${ }^{61}$

Solidarity's denunciation of the Bisbee deportation indicates several ways in which the war environment reinforced discursive tendencies within the IWW that ultimately undermined its potential as an inclusive social movement. In its emphasis on reclaiming manhood from industrial and patriotic servility and protecting working-class masculinity, the IWW attempted to counter the statesponsored machismo of militarism and patriotism. By transcoding what manhood meant to a militant and solidaristic working class, the IWW tried to carve out an alternative or oppositional masculinism. However, in the process the IWW incurred the repressive wrath of the state while downplaying the critical role that women performed in sustaining those communal connections essential to the success and perseverance of any social movement. ${ }^{62}$ For those of us studying those movements, as historians or partisans or both, we need to pay special attention to how gender constructions are imbricated in working-class lives and in the struggles to realize dignity and solidarity, whether in the workplace or the community at large.

\section{Notes}

1. For help and advice along the way, thanks to colleagues in New Zealand and Australia, especially Verity Burgmann at the University of Melbourne, and to the editors and anonymous readers at Left History.

2. Leon Fink, "Culture's Last Stand? Gender and the Search for Synthesis in American Labor History," in In Search of the Working Class: Essays in American Labor History and Political Culture, ed. Fink (Urbana: University of Illinois Press, 1994), 236 and 242.

3. Ava Baron, "Gender and Labor History: Learning from the Past, Looking to the Future," in Work Engendered: Toward a New History of American Labor, ed. Ava Baron (Ithaca, NY: Cornell University Press, 1991), 36.

4. On the role of these syndicalist and IWW migratory workers circulating in North American, New Zealand, and Australia, see Francis Shor, "Left Labor Agitators in the Pacific Rim of the Early Twentieth Century," International Labor and Working-Class History 67 (2005): 148-163.

5. Salvatore Salerno, Red November/Black November: Culture and Community in the Industrial Workers of the World (Albany: State University of New York Press, 1989), 26. For a reference to the IWW as a "revolutionary agitational body," see Patrick Renshaw, The Wobblies: The Story of the IWW and Syndicalism in the United States (Chicago: Ivan R. Dee, 1999), 216.

6. On the dual level of the syndicalist social movement, see Bob Holton, British Syndicalism, 1900-1914: Myths and Realities (London: Pluto Press, 1976), especially 20-21. For an explanation of the discursive community, see Robert Wuthnow, 
Communities of Discourse: Ideology and Social Structure in the Reformation, the Enlightenment, and European Socialism (Cambridge, MA: Harvard University Press, 1989), 13.

7. Wayne Thorpe, "The Workers Themselves": Revolutionary Syndicalism and International Labour, 1913-1923 (Dordrecht: Kluwer Academic, 1989). On the international and comparative context for the emergence of syndicalism, see Marcel van der Linden and Wayne Thorpe, eds., Revolutionary Syndicalism: An International Perspective (Aldershot: Scholar Press, 1990); and Larry Peterson, "The One Big Union in International Perspective: Revolutionary Industrial Unionism, 1900-1925," in Work, Community, and Power: The Experience of Labor in Europe and America, 1920-1925, eds., James E. Cronin and Carmen Siriani (Philadelphia: Temple University Press, 1983), 49-87.

8. Industrial Workers of the World, Proceedings of the First Convention of the Industrial Workers of the World, New York, 1905, 5-6.

9. For a biographical overview of De Leon, see Glen L. Seretan, Daniel De Leon: The Odyssey of an American Marxist (Cambridge, MA: Harvard University Press, 1979). For the De Leonite influence in Canada, see A. Ross McCormack, Reformers, Rebels, and Revolutionaries: The Western Canadian Radical Movement, 1899-1919 (Toronto: University of Toronto Press, 1977), 100-101.

10. For a discussion of the factional background and development of the IWW in New Zealand and Australia, respectively, see Erik Olssen, The Red Feds: Revolutionary Industrial Unionism and the New Zealand Federation of Labour 1908-1914 (Auckland: Oxford University Press, 1988); and Verity Burgmann, Revolutionary Industrial Unionism: The Industrial Workers of the World in Australia (Melbourne: Cambridge University Press, 1995).

11. For recent articles on the comparative labour history of the United States and Australia, see Aurora Bosch, "Why is There No Labor Party in the United States? A Comparative New World Case Study: Australia and the US, 1873-1914," Radical History Review 67 (1997): 35-78; and Greg Patmore, "Australian Labor Historiography: The Influence of the USA," Labor History 37 (1996): 520-34. For an excellent overview of the comparisons between the Australian and US IWW, see Verity Burgmann, "Antipodean Peculiarities: Comparing the Australian IWW with the American," Labor History 40 (1999): 371-92.

12. Peter Stearns, Be a Man! Males in Modern Society, 2nd edition (New York: Holmes \& Meier, 1900), 100. On the construction of hegemonic and other masculinities, see R. W. Connell, Masculinities (Berkeley: University of California Press, 1995). For an overview of hegemonic masculinity in the United States and its alternatives, see Michael Kimmel, Manhood in America: A Cultural History (New York: The Free Press, 1996); and Toby L. Ditz, "The New Men's History and the Peculiar Absence of Gendered Power: Some Remedies from Early American Gender History," Gender \& History 16 (2004): 1-35. For a discussion of the masculinist dimensions of trans-Tasman labour, see Bruce Scates, "Mobilizing Manhood: Gender and the Great Strike in Australia and Aotearoa/New Zealand," Gender \& History 9 (1997): 285-309. On the "larrikin mode of class struggle" as alternative or oppositional masculinsim in Australia, see Andrew Metcalfe, "Sex and Solidarity: Fraternity, Patriarchy and Labour History," in Challenges to Labour History, ed. Terry Irving (Sydney: University of New South 
Wales Press, 1994), 88-113. On an equivalent to larrikin masculinity in the Canadian context, see Steven Maynard, "Rough Work and Rugged Men: The Social Construction of Masculinity in Working-Class History," Labour/Le Travail 23 (1989): 159-69.

13. Eric Hobsbawm, The Age of Empire, 1875-1914 (New York: Vintage Books, 1989), 134. Lasch's discussion of the "syndicalist moment" can be found in his, The True and Only Heaven: Progress and Its Critics (New York: Norton, 1991), 296-328.

14. Francis Shor, "Masculine Power and Virile Syndicalism: A Gendered Analysis of the IWW in Australia," Labour History 63 (1992): 83-99; and "'Virile Syndicalism' in Comparative Perspective: A Gender Analysis of the IWW in the United States and Australia," International Labor and Working Class History 56 (1999): 65-77.

14. Direct Action, 1 July 1915, 1. For a variation on virile syndicalism in the Canadian context, see Todd McCallum, "Not a Sex Question?: The One Big Union and the Politics of Radical Manhood," Labour/Le Travail 42 (1998): 15-54.

16. Joan Wallach Scott, Gender and the Politics of History (New York: Columbia University Press, 1988), 45.

17. Jean Baudrillard, The Mirror of Production, trans. Mark Poster (St. Louis: Telos Press, 1975).

18. For an introduction to Foucault's perspectives on power as a strategic force field and the "individualizing techniques of power," see his Discipline and Punish: The Birth of the Prison, trans. Alan Sheridan (New York: Vintage Books, 1977); The History of Sexuality, Volume I: An Introduction, trans. Robert Harley (New York: Pantheon Books, 1978); and "The Subject of Power," in Michel Foucault: Beyond Structuralism and Hermeneutics, eds., Hubert L. Dreyfuss and Paul Rabinow (Chicago: University of Chicago Press, 1982), 208-26. On the connections between Foucault's strategic force field and the role of gender in history and politics, see Scott, Gender and the Politics of History, 42.

19. Dipesh Chakrabaty, Rethinking Working-Class History: Bengal 1890-1940 (Princeton, NJ: Princeton University Press, 1989), 6 and xii.

20. Kenneth H. Tucker, Jr., French Revolutionary Syndicalism and the Public Sphere (New York: Cambridge University Press, 1996), 55.

21. On the proletarian public sphere, see Oskar Negt and Alexander Kluge, Public Sphere and Experience: Towards an Analysis of the Bourgeois and Proletarian Public Sphere, trans. Peter Labanyi, et. al., (Minneapolis: University of Minnesota Press, 1993).

22. Tera Hunter, To 'joy My Freedom: Southern Black Women's Lives and Labors After the Civil War (Cambridge, MA: Harvard University Press, 1997); Gunther Peck, Reinventing Free Labor: Padrones and Immigrant Workers in the North American West, 1880-1930 (New York: Cambridge University Press, 2000); and George Chauncey, Gay New York: Gender, Urban Culture, and the Makings of the Gay Male World, 1890-1940 (New York: Basic Books, 1994).

23. Nancy Fraser, Justice Interruptus: Critical Reflections on the 'Postsocialist' Condition (New York: Routledge, 1997), 75, 81, and 82. Leela Fernandes's study of the politics of gender, class, and culture in the Calcutta Jute mills directly appropriates Fraser's insights concerning the counterpublic and complicates them. See Leela Fernandes, Producing Workers: The Politics of Gender, Class, and Culture in the Calcutta Jute Mills (Philadelphia: University of Pennsylvania Press, 1997), 109-36. For 
an application of Fraser to syndicalism and the IWW in New Zealand, see Francis Shor, "'Bringing the Storm': Syndicalist Counterpublics and the Industrial Workers of the World in New Zealand, 1908-1914," in On the Left: Essays on Socialism in New Zealand, eds. Pat Moloney and Kerry Taylor (Dunedin: University of Otago Press, 2002), 59-72.

24. On Auckland's ambience, see Olssen, The Red Feds, esp. 108-9. On the resonance between logging communities and the IWW, see Richard A. Rajala, "A Dandy Bunch of Wobblies: Pacific Northwest Loggers and the Industrial Workers of the World, 19001930," Labor History 37 (1996): 205-34.

25. Tom Barker, Tom Barker and the IWW, ed., E. C. Fry (Canberra, 1965), 8.

26. David Montgomery, The Fall of the House of Labor: The Workplace, the State, and American Labor Activism, 1865-1925 (New York: Cambridge University Press, 1987), 310. Howard Kimeldorf identifies a much broader syndicalist current among US workers, albeit divided into the business or "pure-and-simple" syndicalism of the AFL versus the industrial or revolutionary syndicalism of the IWW. See Howard Kimeldorf, Battling for American Labor: Wobblies, Craft Workers, and the Making of the Union Movement (Berkeley: University of California Press, 1999).

27. Burgmann, Revolutionary Industrial Unionism.

28. Olssen, The Red Feds, esp. 72-86.

29. Joy Damousi, Women Come Rally: Socialism, Communism and Gender in Australia, 1890-1955 (Melbourne: Oxford University Press, 1994), p. 88.

30. Walker Smith, "Sabotage," Direct Action, August 14, 1914, 3. On the changing nature of work and shop-floor politics, see Peter Stearns, Lives of Labour: Work in a Maturing Industrial Society (London: Croon Helm, 1975); and David Montgomery, Worker's Control in America: Studies in the History of Work, Technology, and Labor Struggles (New York: Cambridge University Press, 1979). For a fascinating study of the connections between the control of work and the social implications of the restructuring of character and the end of the nineteenth and beginning of the twentieth century, see Anson Rabinbach, The Human Motor: Energy, Fatigue, and the Origins of Modernity (New York: Basic Books, 1990).

31. Melvyn Dubofsky, "The Rise and Fall of Revolutionary Syndicalism in the United States," in van der Linden and Thorpe, Revolutionary Syndicalism, 208.

32. Solidarity, 11 August 1917, 2.

33. Cited in David Roediger, "Gaining a Hearing for Black-White Unity: Covington Hall and the Complexities of Race, Gender, and Class," in Roediger, Towards the Abolition of Whiteness (New York: Verso, 1994), 127. For other examples of how race and ethnicity informed and complicated the appeals of radical labor in general and the IWW in particular, see Gunther Peck, Reinventing Free Labor, esp. 204-225; Philip J. Dreyfus, "The IWW and the Limits of Inter-Ethnic Organizing: Reds, Whites, and Greeks in Grays harbor, Washington, 1912," Labor History 38 (1997): 450-70; and Daniel Rosenberg, "The IWW and Organization of Asian Workers in Early Twentieth Century America," Labor History 36 (1995): 77-87. On the anti-racism of the Australian IWW, see Burgmann, Revolutionary Industrial Unionism, 79-91.

34. Quoted in ibid., 148.

35. Quoted in Stanley Roche, The Red and the Gold: An Informal Account of the Waihi Strike, (Auckland: Oxford University Press, 1982), 62. 
36. Ibid., 99. On Massey's decision to deploy additional police, see Olssen, The Red Feds, 153-5.

37. Olssen, The Red Feds, 159; and Roche, The Red and the Gold, 100-4.

38. Ardis Cameron, Radicals of the Worst Sort: Laboring Women in Lawrence, Massachusetts, 1860-1912 (Urbana: University of Illinois Press, 1993). For a discussion of the ethnic and gender tensions among Italian syndicalists in the Lawrence strike, see Michael Miller Topp, "The Lawrence Strike: The Possibilities and Limitations of Italian American Syndicalist Transnationalism," in Italian Workers of the World: Labor Migration and the Formation of Multiethnic States, eds., Donna R. Gabaccia and Fraser M. Ottanelli (Urbana: University of Illinois Press, 2001), 139-59. For additional perspectives on the role of women in the IWW in the United States and Australia, see Meredith Tax, The Rising of the Women (New York: Monthly Review Press, 1980); Vincent Di Girolamo, "The Women of Wheatland: Female Consciousness and the 1913 Wheat Hop Strike," Labor History 34 (1993): 236-55; Colleen O'Neill, "Domesticity Deployed: Gender, Race, and the Construction of Class Struggle in the Bisbee Deportation," Labor History 34 (1993): 256-73; Burgmann, Revolutionary Industrial Unionism, 92-110; and Damousi, Women Come Rally, 41-7.

39. Laura Lee Downs, "Women's Strikes and the Politics of Popular Egalitarianism in France, 1916-1918," in Rethinking Labor History, ed., Lenard R. Berlanstein (Urbana: University of Illinois Press, 1993), esp.132-33.

40. On the US IWW opposition to the war, see Francis Shor, "The IWW and Oppositional Politics in World War I: Pushing the System Beyond its Limits," Radical History Review 64 (1996): 74-94. On the Australian IWW and the war, see Burgmann, Revolutionary Industrial Unionism, 181-202; and Frank Cain, The Wobblies at War: A History of the IWW and the Great War in Australia (Melbourne: Spectrum, 1993). For comparative perspectives of the US and Australian IWW, see Burgmann, "Antipodean Peculiarities," and Shor, "Virile Syndicalism' in Comparative Perpsective." On the gender discourse in the Australian IWW, see Francis Shor, "Masculine Power and Virile Syndicalism."

41. On the IWW influence in Broken Hill, see George Dale, The Industrial History of Broken Hill (Melbourne: Fraser \& Jenkinson, 1918); Robin Gollan, The Coalminers of New South Wales: A History of the Union, 1860-1960 (London: Cambridge University Press, 1963); and Brian Kennedy, Silver, Sin, and Sixpenny Ale: A Social History of Broken Hill, 1883-1921 (Melbourne: Melbourne University Press, 1978), 124-37. On the IWW critique of labor politicians, their union policies, and strikes of the period, see Burgmann, Revolutionary Industrial Unionism, 143-80. For an extended discussion of the anti-conscription and anti-war campaigns of the Australian IWW, see Cain, The Wobblies at War.

42. Quoted in Salerno, Red November/Black November, 8. Salerno incorporates this insight into his discussion of the IWW mixed local as a center of IWW activity without, however, acknowledging its gender overtones. For a discussion of the IWW and those gender overtones in the logging camps of the Northwest, see Rajala, "A Dandy Bunch of Wobblies." For the gender implications among immigrant workers in the mining camps of the West, see Peck, Reinventing Free Labor.

43. Barker, 35.

44. Direct Action, 31 March 1914, 4. 
45. Direct Action, 27 November 1915, 1. The IWW in the US also saw agitation as its primary function as attested to by one Wobbly organizer who recalled, "The priority ... was agitation. That's what it was. The priority was let's bring on the storm." Quoted in Salerno, Red November, 26.

46. Ian Bedford, "The One Big Union, 1918-1923," in Initiative and Organization, eds. Ian Bedford and Ross Curnow (Melbourne: F. N. Cheshire, 1963), 39.

47. Tom Glynn, Direct Action, 6 November 1915, 1.

48. Direct Action, 15 August 1915,3 . Given the date of the article, it was truly prophetic about the silencing of labor agitators and the suppression of liberties, especially visà-vis the IWW.

49. Direct Action, 10 August 1914, 1.

50. Direct Action, 10 February 1917, 1.

51. Solidarity, 5 February 1916, 3.

52. Solidarity, 15 December 1915, 2.

53. Quoted in Dubofsky, We Shall Be All: A History of the Industrial Workers of the World (New York: Quadrangle, 1973), 358. Also, for an inclusive overview of the IWW organizing in the war years, see ibid., 291-375. For a general history of IWW activities in the Pacific Northwest, see Robert L. Tyler, Rebels of the Woods: The IWW in the Pacific Northwest (Eugene: University of Oregon, 1967).

54. Ralph Chaplin, Wobbly: The Rough-and-Tumble Story of an American Radical (Chicago: The University of Chicago Press, 1948), 208. On the IWW's organizing in the southwest through the AWO, see, for example. Nigel Anthony Sellars, Oil, Wheat, and Wobblies: The Industrial Workers of the World in Oklahoma, 1905-1930 (Norman: University of Oklahoma Press, 1998).

55. Solidarity, 24 March 1917. On the negative repercussions of the IWW" "cult of masculinity" in the US, see Elizabeth Faue, Community of Suffering and Struggle: Women, Men, and the Labor Movement in Minneapolis, 1915-1945 (Chapel Hill: University of North Carolina Press, 1991), 4-15, and 94-5.

56. Solidarity, 26 May 1917, 2.

57. Solidarity, 23 June 1917, 1. On the success of anti-conscription campaigns in Australia, see Margaret Levi, Consent, Dissent, and Patriotism (New York: Cambridge University Press, 1997), 121-3. On the IWW's anti-war activity in Australia during the anti-conscription campaigns, see Burgmann, Revolutionary Industrial Unionism, 181202; and Cain, The Wobblies at War, passim. The percentage of Wobblies who resisted the draft in the US is subject to debate. Unfortunately, too many historians have relied on a figure of $95 \%$ registration, a figure, as I've tried to demonstrate previously, that was concocted to protect the IWW from federal prosecution. See Shor, "The IWW and Oppositional Politics in World War One," esp. 84-86; and Shor, "Reply to Dubofsky," Radical History Review 67 (1997), 214. For a recent incorporation of the 95\% figure, see Sellars, Oil, Wheat, and Wobblies, 95.

58. Solidarity, 28 July 1917, 8.

59. Quoted in Irving Westein, Pie in the Sky: An American Struggle, the Wobblies, and Their Times (New York: Delacorte Press, 1969), 120.

60. William Preston, Jr. Aliens and Dissenters: Federal Suppression of Radicals, 19031933 (Cambridge, MA: Harvard University Press, 1963), 91.

61. Solidarity, 23 June 1917, 1 and 2. 
62. On women's role in developing the communal connections for the IWW, see Cameron, Radicals of the Worst Sort, 75-186. On women and the IWW in Australia, see Burgmann, Revolutionary Industrial Unionism, 92-110. For an overview of the IWW role in Bisbee and the ensuing vigilante action, see Dubofsky, We Shall Be All, 385-91; and Christopher Capozzola, "The Only Badge Needed is Your Patriotic Fervor: Vigilance, Coercion, and the Law in World War I in America, The Journal of American History 88 (2002): 1364-9; and O'Neill, "Domesticity Deployed."

63. See, for example, Sonya O. Rose, "Gender and Labor History: The Nineteenth Century Legacy," International Review of Social History 38 (1993): 145-62. 